\title{
Calcium Intake in Relation to Body Mass Index and Fatness in Thai School-Aged Children
}

\author{
Uruwan Yamborisut ${ }^{1 *}$, Wanphen Wimonpeerapattana ${ }^{2}$, Nipa Rojroongwasinkul', \\ Atitada Boonpraderm 3 , Sayamon Senaprom², Wiyada Thasanasuwan', Ilse Khouw ${ }^{5}$, \\ Paul Deurenberg6 \\ ${ }^{1}$ Human Nutrition Unit, Institute of Nutrition, Mahidol University, Salaya, Thailand \\ ${ }^{2}$ Biostatistics Unit, Institute of Nutrition, Mahidol University, Salaya, Thailand \\ ${ }^{3}$ Community Nutrition Unit, Institute of Nutrition, Mahidol University, Salaya, Thailand \\ ${ }^{4}$ Nutrition Physiology Unit, Institute of Nutrition, Mahidol University, Salaya, Thailand \\ ${ }^{5}$ Friesland Campina, Amersfoort, The Netherlands \\ ${ }^{6}$ Nutrition Consultant, Langkawi, Malaysia \\ Email: "uruwan.yam@mahidol.ac.th
}

Received 16 March 2015; accepted 4 May 2015; published 6 May 2015

Copyright (C) 2015 by authors and Scientific Research Publishing Inc.

This work is licensed under the Creative Commons Attribution International License (CC BY). http://creativecommons.org/licenses/by/4.0/

c) (i) Open Access

\begin{abstract}
An emerging evidence suggests that dietary calcium may play a role in the regulation of body weight in humans. This study examined the relationship of calcium intake with body mass index and body fatness in Thai children. Methods: A cross-sectional study in 1570, 6 - 12 year-old children were conducted in representative provinces of Thailand. Body weight, height, sitting height and 4 sites skinfolds thickness were measured as well as the dietary intake using a $24 \mathrm{~h}$ recall and a food frequency questionnaire (FFQ). General linear model (GLM) analysis was used to determine the effect of calcium intake on body mass index (BMI) and body fatness of children. Results: There were no differences in parental education and family's socio-economic status between genders. Girls had significantly greater sitting height $(p=0.035)$, sitting height to height ratio $(p=0.014)$ and sum of four skinfold thickness $(p=0.001)$ than boys. Mean calcium intake was lower in girls than in boys. GLM analysis demonstrated that lower calcium intake among children was associated with higher body weight, BMI and sum 4-skinfold thickness. Conclusion: Lower calcium intake is associated with higher BMI and body fatness of Thai children. Further studies need to determine the optimal calcium intake to prevent overweight and obesity in children.
\end{abstract}

\section{Keywords}

Thai Children, Calcium Intake, Milk, Skinfold Thickness, Body Mass Index

\footnotetext{
${ }^{*}$ Corresponding author.
}

How to cite this paper: Yamborisut, U., Wimonpeerapattana, W., Rojroongwasinkul, N., Boonpraderm, A., Senaprom, S., Thasanasuwan, W., Khouw, I. and Deurenberg, P. (2015) Calcium Intake in Relation to Body Mass Index and Fatness in Thai School-Aged Children. Open Journal of Pediatrics, 5, 104-112. http://dx.doi.org/10.4236/ojped.2015.52016 


\section{Introduction}

The increasing prevalence of childhood obesity is a global public health problem [1] [2] as obesity is associated with increased risk of non-communicable chronic diseases such as diabetes, dyslipidemia, hypertension and cardiovascular disease in later life [3] [4]. The development of obesity is caused by multiple factors. Besides genetics, environmental factors affecting changes in dietary pattern and lifestyle appear to be important determinants for the increasing adiposity prevalence. It is known that excess energy intake for an extended period will lead to an increase in body weight. Additionally, emerging evidence suggests that dietary calcium may play a role in the regulation of body weight and body fat [5] [6]. Results from cross-sectional studies showed an inverse association between calcium and body mass index among adolescents and adults [7] [8]. Longitudinal studies in children and adolescents also indicated an inverse association between calcium intake and body fat or sum of skinfolds [9] [10] whilst randomized controlled trials revealed inconsistent results [11] [12]. In adults, high calcium intake was also found to be negatively correlated with plasma LDL-cholesterol and total cholesterol after adjustment for body fat and waist circumference [13]. In most diets, dairy contributes substantially to calcium intake. Regarding the role of dairy consumption on the development of obesity, a recent systematic review of 19 prospective studies has shown both positive and negative effects of dairy intake as well as no impact on weight gain in human subjects [14].

Thailand has experienced a rapid socio-economic development over the last few decades. This economic transformation included a process of urbanization and nutrition transition, thereby, bringing about an increasing prevalence of childhood obesity. When using weight-for-height as criteria, the prevalence of obesity increased from $5.8 \%$ to $7.9 \%$ for preschool children and from 5.8\% to 6.7\% for school-aged children from 1997 to 2001 [15]. A recent nutrition survey in 3119 Thai infants and children, aged 6 months - 12 years, from 4 regions of Thailand including Bangkok, showed an overall prevalence of childhood obesity of $11.8 \%$ for municipal and $5.9 \%$ for non-municipal areas and the highest proportion of obese children was found among the school-age group ( 6 to 12 years). The prevalence of underweight ranged between $6.4 \%-10.2 \%$ and the stunting prevalence in non-municipal areas was twice as high as in municipal areas; $8.4 \%$ versus $4.1 \%$ [16]. Furthermore, results showed that calcium, iron and vitamin $C$ intakes of children were relatively low compared to the recommendation [16]. Therefore, the aim of this study was to investigate the relationship between calcium intake and adiposity of Thai school-aged children.

\section{Material and Methods}

\subsection{Study Design}

This study was part of the South East Asian Nutrition Survey (SEANUTS) which aimed to examine nutritional status and nutrient intakes of infants and children, aged 6 months - 12 years, in Indonesia, Malaysia, Vietnam, and Thailand [16]. The survey in Thailand was carried out in four regions of the country during January-August 2011. The study was conducted according to the guidelines of the Declaration of Helsinki and approved by the Ethics Committee on Research involving Human Subjects of the Faculty of Medicine, Ramathibodi Hospital, Mahidol University (MURA 2010/467), Thailand. Written consent was obtained from parents or caretakers of the children. The study is registered in the Dutch trial register as NTR2462.

\subsection{Study Population}

Subjects were 1570, 6 - 12 year-old children whose families were residing in provinces located in 4 regions of Thailand. Multi-stage random sampling technique was applied to recruit the children. The representative province was sampled for each region, i.e., Lop Buri province for the Central, Chiang Mai province for the North, Si SaKet and Kalasin provinces for the Northeast and Phang-nga province for the South region of Thailand. Bangkok (the Central region) was also chosen. Then each province was stratified according to proportion of municipal to non-municipal areas and subsequently villages were randomly selected as target groups. The target number of children was determined based on their proportion to the overall number of 6 - 12 year-old children in the specified regions.

\subsection{Data Collection}

Data collection was performed at health centers in each district. Information of demographic characteristics of 
the children's families was obtained by interviewing parents and/or care takers using structured questionnaires.

\subsubsection{Anthropometric Measurements}

Body weight was measured using a digital weighing scale (Seca Model 882, GmbH \& Co., Hamburg, Germany) to the nearest $0.1 \mathrm{~kg}$. Standing height was measured with a stadiometer (Microtoise, Stanley-Mabo ${ }^{\circledR}$, Poissy, France) to the nearest $0.1 \mathrm{~cm}$. Body mass index (BMI) was calculated as body weight divided by height squared $\left(\mathrm{kg} / \mathrm{m}^{2}\right)$. Sitting height $(\mathrm{SH})$ was measured with the subject sitting on a flat hard stool with the buttocks in contact with the backboard of the stadiometer while the legs were supported by a footrest so that the child's thighs were horizontal. The height of the stool was subtracted from the readings. Sitting height ratio (SHR) was calculated as $\mathrm{SH} /$ standing height $\times 100$. Skinfold thickness was measured at four anatomical sites using a skinfold caliper (Holtain Ltd., Crymych, UK) to the nearest $0.2 \mathrm{~mm}$. The triceps skinfold was measured on the left arm midway between the acromion process of the scapula and the olecranon process of the ulna. The biceps skinfold was measured at the same level as the triceps skinfold. The subscapular skinfold was measured just below and parallel to the medial border of the scapula at an angle of $45^{\circ}$ and the supra-iliac skinfold was measured at the mid-axillary line, just above the left iliac crest and $45^{\circ}$ towards the front of the body. Skinfold measurements were taken in triplicate and the average value was used in the statistics. The sum of four skinfolds was used as indicator of body fatness.

\subsubsection{Dietary Assessment}

Dietary assessment in children was performed using a semi-quantitative food frequency questionnaire covering the past month to estimate daily milk intake and the use of a 24-hour food recall to determine dietary calcium of children. For children aged $<10$ years, the information on food intakes and consumption frequency was obtained from children's mothers, whereas for children aged $>10$ years, food intake data were from interviews with the children. Household measuring cups and/or spoons and pictorial food models were used to estimate food portion size and the amount of cooked rice consumed by the children was also weighed. All food codes were converted and analyzed for nutrient intakes using the INMUCAL-N V2.0 (Institute of Nutrition, Mahidol University) program. Since only one $24 \mathrm{~h}$ recall was obtained, the estimating nutrient intake distributions of children were performed using external variance estimates to correct for day-to-day within person variation. The principle method has been described elsewhere [17] [18] and the Personal Computer Version of Software for Intake Distribution Estimation (PC-SIDE) was applied to determine the estimates of nutrient intakes of children [19].

\subsection{Statistical Analysis}

Data analysis was performed using Predictive Analytics Software Statistics (PASW) version 18 (SPSS Inc., Chicago, IL, USA). Results of anthropometric variables and nutrient intakes of children are presented as mean, standard deviation (SD) and median. The Kolmogorov Smirnov test was used to test normality of data and data that was not normally distributed were log-transformed and the transformed data were used in the statistics. Qualitative characteristics of children's families were compared using Chi-squared test. Mean differences in anthropometric indices and nutrient intakes between boys and girls were tested using Student's t-test and the Mann Whitney test. Calcium intake of children was categorized in tertiles and analysis of variance (ANOVA) was used to determine mean differences in variables between the three tertiles of calcium intake groups. General Linear Model (GLM) procedure was used to test the effect of calcium intake on body weight, body mass index and body fatness, after correcting for the confounding effects of gender, age, residential area, mother's education, family income, sitting height and energy intake. Statistical difference was set at $p<0.05$.

\section{Results}

Table 1 shows the socio-demographic characteristics of the children's families. The proportion of children in non-municipal areas was twice as high as that of municipal areas but there was no significant difference in proportion between boys and girls. There was also no difference in the education background of the children's parents between the genders. It was found that about $50 \%$ of the parents completed primary education level. Around $40 \%$ of the families, earned $6000-14,000$ Baht (approx. $183-427$ USD, 1 USD $=32.7$ THB) per month, whereas the proportion of families with an income of $>14,000$ baht per month was about $31 \%$ of the study group. 
Table 1. Socio-demographic background variables of the study population.

\begin{tabular}{|c|c|c|c|}
\hline Variables & Boys N (\%) & Girls N (\%) & $p$-value ${ }^{c}$ \\
\hline $\begin{array}{l}\text { No. of subjects } \\
\text { Residential area } \\
\text { Municipal } \\
\text { Non-municipal }\end{array}$ & $\begin{array}{c}789 \\
258(32.7) \\
531(67.3)\end{array}$ & $\begin{array}{c}781 \\
253(32.4) \\
528(67.6)\end{array}$ & 0.897 \\
\hline $\begin{array}{l}\text { Education of parents } \\
\text { Child's father } \\
\text { Primary school } \\
\text { Secondary school } \\
\text { Bachelor and higher }\end{array}$ & $\begin{array}{c}372(53.5) \\
268(38.6) \\
55(7.9)\end{array}$ & $\begin{array}{c}362(50.8) \\
282(39.6) \\
69(9.6)\end{array}$ & 0.398 \\
\hline $\begin{array}{l}\text { Child's mother } \\
\text { Primary school } \\
\text { Secondary school } \\
\text { Bachelor and higher }\end{array}$ & $\begin{array}{c}385(52.1) \\
288(39.0) \\
66(8.9)\end{array}$ & $\begin{array}{c}366(49.1) \\
312(41.9) \\
67(9.0)\end{array}$ & 0.491 \\
\hline $\begin{array}{c}\text { Family income (baht/month) } \\
\quad<6000(<183 \text { USD) } \\
6000-14,000(183-427 \text { USD) } \\
>14,000(>427 \text { USD) }\end{array}$ & $\begin{array}{l}238(30.4) \\
295(37.8) \\
249(31.8)\end{array}$ & $\begin{array}{l}221(28.7) \\
308(40.1) \\
240(31.2)\end{array}$ & 0.617 \\
\hline
\end{tabular}

${ }^{a}$ Family income is categorized in tertiles. There were 7 missing records for boy group and 12 missing records for girl group due to the participants did not specify their incomes; ${ }^{\mathrm{b}} 1 \mathrm{USD}=32.7$ baht; ${ }^{\mathrm{C}} \mathrm{P}$-value by Chi-square test.

Table 2 shows the results of anthropometry and nutrient intakes of children. Mean age was $9.4 \pm 2.0$ years for boys and girls, with no difference between the genders. Body weight, body height and BMI of boys were not different from that of girls. However, boys had significantly lower sitting height values $(p=0.035)$ and lower SHR $(p=0.014)$ than girls, meaning the boys' legs were relatively longer. The sum of four skinfolds of girls was significantly greater than that of boys $(p=0.001)$. Boys had significantly higher intakes of energy, protein, fat, carbohydrate $(p=0.001)$ and calcium $(p=0.020)$ than girls. Both boys and girls had noticeably higher protein but lower calcium intakes than the Thai Recommended Dietary Allowances (RDA).

Table 3 shows that children with calcium intakes of $>253 \mathrm{mg} /$ day (upper two calcium intake tertiles) had significantly lower body weight $(p<0.05)$ and sitting height $(p<0.05)$ than those with calcium intakes $<253$ $\mathrm{mg} /$ day (lower calcium intake tertile). Milk consumption was higher in the highest calcium intake tertile.

Table 4 shows that after correcting for confounding variables, children in the lowest two calcium intake tertiles had significantly higher body weight $(p=0.01)$ and BMI $(p=0.025)$ compared to those in the highest calcium intake tertile. Also, children in the lowest calcium intake tertile had significantly higher sum 4-SKF ( $\mathrm{p}=$ 0.039) compared to those in the highest calcium intake tertile (Model I). Likewise, similar results were obtained when percentage ofcalcium intake from milk was the independent variable (Model II). But when milk intake from FFQ was used as independent variable, no effect of milk consumption on body weight, BMI or sum four skinfolds was found (Model III).

\section{Discussion}

Dietary calcium is known to be an essential nutrient for bone accretion and bone health. This study explored the relationship of calcium intake to adiposity in terms of body weight, BMI and subcutaneous body fat of Thai school-aged children. The study population was from low-to-middle socio-economic families in municipal and non-municipal areas. Although there were no differences in age and BMI between the genders, girls had significantly higher sitting height and SHR values than boys. Skeletal dimensions vary with age, gender and ethnicity and probably influence body composition. Children with greater SHR values have relatively short legs [20]. Furthermore, studies have shown that short leg length and SHR were associated with the risk of non-communicable chronic diseases, i.e., hypertension and coronary heart disease [21] [22]. Girls also had a greater sum of skinfolds, thus had more subcutaneous fat than boys of similar age. Body fat is known to be associated with age and gender and a study has shown that female had greater sum of skinfold thicknesses than in males, with a larger increase with age [23].

Boys had significantly higher intakes of energy, protein, fat, carbohydrate and calcium than girls. However, the total calcium intake of both genders was relatively low; at only $42 \%$ and $39 \%$ of Thai RDA for boys and 
Table 2. Anthropometric characteristics and nutrient intakes of the children.

\begin{tabular}{|c|c|c|c|}
\hline Variables & Boys $(N=789)$ & Girls $(N=781)$ & $p$-value ${ }^{\mathrm{g}}$ \\
\hline Age (years) & $9.4 \pm 2.0^{\mathrm{a}}(9.4)^{\mathrm{b}}$ & $9.4 \pm 2.0(9.5)$ & 0.853 \\
\hline Weight (kg) & $30.5 \pm 11.8(27.7)$ & $30.6 \pm 11.4(28.1)$ & 0.805 \\
\hline Height (cm) & $131.7 \pm 12.3(131.0)$ & $132.7 \pm 13.3(131.8)$ & 0.119 \\
\hline Sitting height $(\mathrm{cm})$ & $70.5 \pm 5.8(70.0)$ & $71.4 \pm 6.7(70.8)$ & 0.035 \\
\hline Sitting height ratio (\%) & $53.6 \pm 1.9(53.5)$ & $53.8 \pm 2.0(53.6)$ & 0.014 \\
\hline $\operatorname{BMI}\left(\mathrm{kg} / \mathrm{m}^{2}\right)$ & $17.1 \pm 4.0(15.7)$ & $16.9 \pm 3.7$ (15.9) & 0.403 \\
\hline Sum 4-SKF $(\mathrm{mm})$ & $36.5 \pm 24.4(26.0)$ & $41.8 \pm 22.2(34.4)$ & 0.001 \\
\hline \multicolumn{4}{|l|}{ Nutrient intake } \\
\hline Energy (kcal/day) & $1425 \pm 281(1417)$ & $1302 \pm 241(1293)$ & 0.001 \\
\hline Energy $(\% \mathrm{RDA})^{\mathrm{d}}$ & $91.1 \pm 18(90)$ & $86.1 \pm 16(86)$ & 0.001 \\
\hline Protein (g/day) & $53.1 \pm 14.9(51.1)$ & $47.7 \pm 13.8(47.4)$ & 0.001 \\
\hline Protein ( \% RDA) ${ }^{\mathrm{d}}$ & $155 \pm 45(150)$ & $142 \pm 44.0(136)$ & 0.001 \\
\hline Fat (g/day) & $44.9 \pm 16.2(43.0)$ & $41.3 \pm 13.4(40.1)$ & 0.001 \\
\hline Carbohydrate (g/day) & $202 \pm 44.5$ (198.5) & $184 \pm 45.3(179.6)$ & 0.001 \\
\hline Total calcium intake (mg/day) & $377 \pm 199(352)$ & $351 \pm 183(328)$ & 0.020 \\
\hline Total calcium intake (as\% RDA) ${ }^{\mathrm{d}}$ & $42.0 \pm 23.2(39)$ & $39.2 \pm 20.9$ (37) & 0.034 \\
\hline$\%$ Calcium from milk intake ${ }^{e}$ & $40.7 \pm 33.0$ & $39.2 \pm 32.6$ & 0.381 \\
\hline Milk intake from FFQ, $\mathrm{ml} /$ day $^{\mathrm{f}}$ & $367 \pm 264(320)$ & $343 \pm 215$ (309) & 0.146 \\
\hline
\end{tabular}

${ }^{\mathrm{a}}$ Mean \pm SD; ${ }^{\mathrm{b}}$ Median values in the parentheses; ${ }^{\mathrm{C}}$ Sum 4-SKF, Sum of biceps + triceps + subscapular + supra-iliac skinfold thickness; ${ }^{\mathrm{d}} \mathrm{RDA}$, Thai Recommended Dietary Allowances; ${ }^{e}$ Percentage of calcium from milk intake by 24 h-food recall; ${ }^{\mathrm{f}}$ Milk intake from food frequency questionnaire; ${ }^{\mathrm{g}}$ Significant mean difference between genders by Mann Whitney test for sitting height, sitting height ratio, sum 4-SKF, milk and nutrient intakes.

Table 3. Anthropometric and nutrient intakes of children in tertiles of calcium intake.

\begin{tabular}{|c|c|c|c|}
\hline \multirow{2}{*}{ Variables } & \multicolumn{3}{|c|}{ Calcium intake tertiles } \\
\hline & $<253$ mg/day & 253 - $417 \mathrm{mg} /$ day & $>417$ mg/day \\
\hline Boys: girls (N) & $265: 257$ & $244: 278$ & $280: 243$ \\
\hline Age (years) & $9.8 \pm 2.0^{\mathrm{a}}(9.9)^{\mathrm{d}}$ & $9.4 \pm 2.0^{\mathrm{b}}(9.5)$ & $9.2 \pm 2.0^{\mathrm{b}}(9.0)$ \\
\hline Weight (kg) & $31.8 \pm 12.0^{\mathrm{a}}(28.8)$ & $30.2 \pm 11.8^{\mathrm{b}}(27.1)$ & $29.8 \pm 10.9^{\mathrm{b}}(27.7)$ \\
\hline Height $(\mathrm{cm})$ & $133.9 \pm 12.8^{\mathrm{a}}(133.3)$ & $132.0 \pm 12.8^{\mathrm{b}}(131.0)$ & $130.8 \pm 12.8^{\mathrm{b}}(130.0)$ \\
\hline $\operatorname{BMI}\left(\mathrm{kg} / \mathrm{m}^{2}\right)$ & $17.2 \pm 4.0^{\mathrm{a}}(15.9)$ & $16.8 \pm 3.9^{\mathrm{a}}(15.6)$ & $16.9+3.7^{\mathrm{a}}(15.9)$ \\
\hline Sitting height $(\mathrm{cm})$ & $71.6 \pm 6.2^{\mathrm{a}}(71.2)$ & $70.8 \pm 6.2^{\mathrm{b}}(70.2)$ & $70.3 \pm 6.3^{\mathrm{b}}(69.6)$ \\
\hline Sitting height ratio (\%) & $53.6 \pm 1.6^{\mathrm{a}}(53.5)$ & $53.8 \pm 2.0^{\mathrm{a}}(53.6)$ & $53.8 \pm 2.1^{\mathrm{a}}(53.7)$ \\
\hline Sum 4-SKF $(\mathrm{mm})$ & $40.0 \pm 23.6^{\mathrm{a}}(30.5)$ & $38.1 \pm 23.4^{\mathrm{a}}(28.5)$ & $39.3 \pm 23.5^{\mathrm{a}}(30.6)$ \\
\hline Energy intake (kcal/day) & $1258 \pm 264^{\mathrm{a}}(1223)$ & $1355 \pm 254^{\mathrm{b}}(1337)$ & $1477 \pm 245^{\mathrm{c}}(1462)$ \\
\hline Protein (g/day) & $45.5 \pm 14.0^{\mathrm{a}}(43.8)$ & $50.6 \pm 14.2^{\mathrm{b}}(48.7)$ & $56.7 \pm 13.0^{\mathrm{c}}(55.1)$ \\
\hline Fat (g/day) & $37.3 \pm 14.2^{\mathrm{a}}(35.2)$ & $42.1 \pm 13.6^{\mathrm{b}}(40.0)$ & $50.0 \pm 14.4^{\mathrm{b}}(48.3)$ \\
\hline Carbohydrate (g/day) & $181.7 \pm 47.1^{\mathrm{a}}(175.0)$ & $193.7 \pm 45.3^{\mathrm{b}}(188.9)$ & $203.7 \pm 42.4^{\mathrm{c}}(201.2)$ \\
\hline Milk intake from FFQ (ml/day) & $312 \pm 202^{\mathrm{a}}(283)$ & $337 \pm 199^{\mathrm{b}}(296)$ & $415 \pm 298^{\mathrm{c}}(341)$ \\
\hline
\end{tabular}

Results are from total 1567 children (data of three girls were missing). ${ }^{\mathrm{a}, \mathrm{b}, \mathrm{c}}$ Significant mean difference between groups are denoted with different superscript letters by ANOVA, at $p<0.05$; ${ }^{\mathrm{d}}$ Median values were in parentheses; ${ }^{\text {e}} \mathrm{Sum} 4$ 4-SKF, sum of biceps + triceps + subscapular + supra-iliac skinfolds. 
Table 4. The effect of daily calcium intake on body weight, body mass index (BMI) and body fatness of children.

\begin{tabular}{|c|c|c|c|c|c|c|c|c|c|}
\hline \multirow{2}{*}{ Variables } & \multicolumn{3}{|c|}{ In(Body weight) } & \multicolumn{3}{|c|}{$\ln (\mathrm{BMI})$} & \multicolumn{3}{|c|}{$\ln (\text { Sum 4-SKF) })^{i}$} \\
\hline & $\beta$ & SE & $p$-value & $\boldsymbol{\beta}$ & SE & $p$-value & $\beta$ & SE & $p$-value \\
\hline \multicolumn{10}{|l|}{$\begin{array}{c}\text { Model I I }^{\mathbf{a}} \\
\text { Daily calcium intake }\end{array}$} \\
\hline$<253$ mg/day & 1.05 & 1.02 & 0.002 & 1.04 & 1.01 & 0.003 & 1.07 & 1.03 & 0.039 \\
\hline 253 - 417 mg/day & 1.04 & 1.02 & 0.010 & 1.03 & 1.01 & 0.025 & 1.05 & 1.03 & 0.128 \\
\hline$>417$ mg/day ${ }^{\mathrm{e}}$ & - & - & - & - & - & - & - & - & - \\
\hline Adjusted $\mathrm{R}^{2}$ & \multicolumn{3}{|c|}{0.534} & \multicolumn{3}{|c|}{0.250} & \multicolumn{3}{|c|}{0.235} \\
\hline \multicolumn{10}{|l|}{$\begin{array}{c}{\text { Model } \mathbf{I I}^{\mathbf{b}}} \\
\text { Percentage calcium } \\
\text { intake from milk }\end{array}$} \\
\hline $1^{\text {st }}$ tertile & 1.05 & 1.02 & 0.001 & 1.04 & 1.01 & 0.001 & 1.08 & 1.03 & 0.001 \\
\hline $2^{\text {nd }}$ tertile & 1.02 & 1.02 & 0.219 & 1.01 & 1.01 & 0.342 & 1.02 & 1.03 & 0.543 \\
\hline $3^{\text {rd }}$ tertile $^{\mathrm{f}}$ & - & - & - & - & - & - & - & - & - \\
\hline Adjusted $\mathrm{R}^{2}$ & & 0.534 & & & 0.251 & & & 0.236 & \\
\hline Mndel III ${ }^{\mathrm{C}}$ & & & & & & & & & \\
\hline \multicolumn{10}{|l|}{ Daily milk intake ${ }^{\mathrm{g}}$} \\
\hline$<247 \mathrm{ml} /$ day & -0.98 & 1.02 & 0.453 & -1.00 & 1.01 & 0.674 & -0.99 & 1.03 & 0.727 \\
\hline 247 - $380 \mathrm{ml} /$ day & -0.99 & 1.02 & 0.533 & -0.99 & 1.01 & 0.582 & -0.99 & 1.03 & 0.656 \\
\hline$>380 \mathrm{ml} /$ day $^{\mathrm{h}}$ & - & - & - & - & - & - & - & - & - \\
\hline Adjusted $\mathrm{R}^{2}$ & \multicolumn{3}{|c|}{0.530} & \multicolumn{3}{|c|}{0.245} & \multicolumn{3}{|c|}{0.233} \\
\hline
\end{tabular}

ln, log transformations of the body weight, BMI and sum of 4-skinfolds. a,b,c GLM model is adjusted for gender, age, residential area, child’s mother educational level, family income, sitting height ratio and energy intakes of children; ${ }^{\mathrm{d} C a l c i u m}$ intake is from $24 \mathrm{hr}$ food recall; ${ }^{\mathrm{e}}$ Reference group is calcium intake of $>417 \mathrm{mg} / \mathrm{day}$; ${ }^{\mathrm{f}}$ Reference group is percentage of calcium intake from milk as 3rd tertile; ${ }^{\mathrm{g}}$ Milk intake is from food frequency questionnaire; ${ }^{\text {h }}$ Reference group is milk intake of $>380 \mathrm{ml} /$ day; ${ }^{\mathrm{i}}$ Sum $4-\mathrm{SKF}$, Sum of biceps + triceps + subscapular + supra-iliac skinfolds.

girls, respectively and about half of the children consumed less than $70 \%$ of the RDA of dietary calcium (data not shown). The contribution of percentage calcium from milk intake to children was $39.2 \%-40.7 \%$ of total calcium from all food groups suggesting that milk was the main source of calcium. Average milk intakes of children as assessed by FFQ was relatively low with 367 and $343 \mathrm{ml} /$ day in boys and girls respectively (Table 2). This reported milk intake by FFQ would result in a higher calcium intake of about $249 \mathrm{mg} / \mathrm{day}$. It is well known that FFQ tends to overestimate intakes compared to 24h recall [24]. The reported milk intakes were slightly higher than that reported in the 2009 Thai National Health Examination Surveys which indicated that school-aged children consumed less than $250 \mathrm{ml}$ milk and other dairy products per day [25]. Other potentially calcium sources in the Thai diet could be fish, anchovy and dried shrimp and some vegetables such as kale and amaranth. However, such food intakes were found to be relatively low in children; i.e., average intake of fish and aquatic animal products was only about $11.4 \mathrm{~g} /$ day and the average intake of calcium-rich vegetables was less than $20 \mathrm{~g}$ /day, contributing to total calcium intake for $7.4 \%$ and $4.1 \%$ respectively (data not shown). Therefore, these foods did not substantially contribute to the calcium intake in these children.

The children did not achieve the RDA for calcium (Table 2), which is currently set for this age group at 800 $1000 \mathrm{mg} /$ day. Increasing milk consumption in the Thai diet to $400 \mathrm{ml} /$ day (2 servings/day) as recommended by the Thai Food Based Dietary guideline [26] would increase the calcium intake to approximately $47 \%$ - $60 \%$ of RDA. Also other studies in the Asian region show that calcium intakes of children and adolescents are suboptimal with for example 59\% - 64\% of RDA in Taiwan [27] and 50\% - 60\% of RDA in Korea [28]. Factors affecting milk consumption included urbanization, which leads to changes in food consumption patterns, social and cultural norms and the relative prices of food commodities [29]. Results from nutrition surveys showed that inadequate calcium intake in children may also be related to the replacement of milk as beverage by sweetened soft drinks [30]. Moreover, family environment has been shown to be important for shaping children's eating behaviors. One study demonstrated that milk and soft drink consumption of the mothers predicted their daughters' intakes of such beverages [31]. Although our study did not deeply explore the influence of family environment on children's milk consumption, it has been suggested that parents are role models for their children's eating behaviors. 
When children were categorized in three calcium intake levels, those who had high dietary calcium intakes had significantly lower body weight than children consuming less calcium although they were younger. As the fact that there will be the trend of increasing body weight according to the increasing child's age. However, results from Table 4 indicated that when the child's age and other confounding variables were statistically adjusted in the GLM model, it was found that lower dietary calcium intake was associated with higher body weight, higher BMI and higher sum of skinfold thickness in children. Previous studies on the effect of dietary calcium on the regulation of body weight and body fat showed mixed results. Cross-sectional [7] [32] and longitudinal studies [9] [33] have shown an inverse association between calcium intake and BMI and between calcium intake and body fat among children and adolescents. However, a randomized controlled trial (RCT) study [34] and a review of evidence [35] showed inconsistent results. A possible explanation of the effect of calcium on body fat is, that higher dietary calcium can induce fecal fatty acid excretion [36]. At cellular level, studies in human adipocytes demonstrated that high calcium intake could be linked to decreased intracellular calcium, and thereby, decreased lipogenic gene expression and increased lipolysis [37].

In most diets, milk and dairy products are a major contributor to calcium intake. The fact that in this study no effect of milk intake from FFQ was found can have various reasons. First, it seems likely that the reported milk intake is an overestimation as in general FFQ tends to overestimate intakes [24]. Secondly, with the relatively low milk consumption pattern of the children, the contribution of milk to calcium intake is relatively low with on average 52\%, thus a possible effect is more difficult to detect. This is also obvious from the results of model II in Table 4. Thirdly, depending on the type of milk consumed (skimmed or full cream), a possible positive effect of calcium in milk might be counterbalanced by a higher total fat consumption although total energy intake was corrected for in the analyses. A review of the literature showed either beneficial or neutral effects of dairy foods on body weight or body composition [38].

The strength of the present study is that the sample of children was obtained from multi-stage random sampling from all regions of Thailand, and therefore, the results can be seen as representative for the country. A limitation of this study is that food recall for each child were performed for only one day, which did not take into account the variation in nutrient intakes. In addition, body fat of the children was not directly measured, which might misclassify some children with a high BMI due to high lean body mass.

\section{Conclusion}

This study demonstrated that a lower calcium intake was associated with a higher body weight, BMI and skinfold thickness in Thai school-aged children. Future randomized controlled trial studies are needed to examine whether individual dairy food items, as main calcium contributors in the diet, may play a protective role on weight status, body proportion and/or body composition.

\section{Acknowledgements}

The study was funded by Royal Friesland Campina Innovation. The authors would like to thank Ms JutatipWangsai and Ms Chumapa Deesudchit from Friesland Campina Thailand for their role in facilitating the research project. The authors are very grateful to all parents and children for their co-operation during data collection. Also, special thanks to all health care personnel at district health centers.

\section{Conflict of Interest}

The authors declared no conflict of interest.

\section{References}

[1] de Onis, M., Blossner, M. and Borghi, E. (2010) Global Prevalence and Trends of Overweight and Obesity among Preschool Children. American Journal of Clinical Nutrition, 92, 1257-1264. http://dx.doi.org/10.3945/ajcn.2010.29786

[2] Rivera, J.A., de Cossío, T.G., Pedraza, L.S., Aburto, T.C., Sánchez, T.G. and Martorell, R. (2014) Childhood and Adolescent Overweight and Obesity in Latin America: A Systematic Review. Lancet Diabetes Endocrinol, 2, 321-332. http://dx.doi.org/10.1016/S2213-8587(13)70173-6

[3] Reilly, J.J. and Kelly, J. (2011) Long-Term Impact of Overweight and Obesity in Childhood and Adolescence on Morbidity and Premature Mortality in Adulthood: Systematic Review. International Journal of Obesity, 35, 891-898. 
http://dx.doi.org/10.1038/ijo.2010.222

[4] Freedman, D.S., Mei, Z., Srinivasan, S.R., Berensen, G.S. and Dietz, W. (2007) Cardiovascular Risk Factors and Excess Adiposity among Overweight Children and Adolescents: The Bogalusa Heart Study. Journal of Pediatrics, 150, 12-17. http://dx.doi.org/10.1016/i.jpeds.2006.08.042

[5] Heaney, R.P., Davies, K.M. and Barger-Lux, M.J. (2002) Calcium and Weight: Clinical Studies. Journal of the American College of Nutrition, 21, S152-S155. http://dx.doi.org/10.1080/07315724.2002.10719213

[6] Zemel, M.B., Shi, H., Greer, B., Dirienzo, D. and Zemel, P.C. (2000) Regulation of Adiposity by Dietary Calcium. FASEB Journal, 14, 1132-1138.

[7] Palacios, C., Benedetti, P. and Fonseca, S. (2007) Impact of Calcium Intake on Body Mass Index in Venezuelan Adolescents. PR Health Sciences Journal, 26, 199-204.

[8] Loos, R.J., Rankinen, T., Leon, A.S., Skinner, J.S., Wilmore, J.H., Rao, D.C., et al. (2004) Calcium Intake Is Associated with Adiposity in Black and White Men and White Women of the HERITAGE Family Study. Journal of Nutrition, 134, 1772-1778.

[9] Skinner, J.D., Bounds, W., Carruth, B.R. and Ziegler, P. (2003) Longitudinal Calcium Intake Is Negatively Related to Children's Body Fat Indexes. Journal of the American Dietetic Association, 103, 1626-1631. http://dx.doi.org/10.1016/j.jada.2003.09.018

[10] Boon, N., Koppes, L.L., Saris, W.H. and Van Mechelen, W. (2005) The Relation between Calcium Intake and Body Composition in a Dutch Population: The Amsterdam Growth and Health Longitudinal Study. American Journal of Epidemiology, 162, 27-32. http://dx.doi.org/10.1093/aje/kwi161

[11] Zemel, M.B., Thompson, W., Milstead, A., Morris, K. and Campbell, P. (2004) Calcium and Dairy Acceleration of Weight and Fat Loss during Energy Restriction in Obese Adults. Obesity Research, 12, 582-590.

http://dx.doi.org/10.1038/oby.2004.67

[12] Yanoski, J.A., Parikh, S.J., Yanoff, L.B., Denkinger, B.I., Calis, K.A., Reynolds, J.C., et al. (2009) Effect of Calcium Supplementation on Body Weight and Adiposity in Overweight and Obese Adults: A Randomized Trial. Annals of Internal Medicine, 150, 821-829. http://dx.doi.org/10.7326/0003-4819-150-12-200906160-00005

[13] Jacqmain, M., Doucet, E., Despres, J.-P., Bouchard, C. and Tremblay, A. (2003) Calcium Intake, Body Composition and Lipoprotein-Lipid Concentrations in Adults. The American Journal of Clinical Nutrition, 77, 1448-1452.

[14] Louie, J.C.Y., Flood, V.M., Hector, D.J., Rangan, A.M. and Gill, T.P. (2011) Dairy Consumption and Overweight and Obesity: A Systematic Review of Prospective Cohort Studies. Obesity Reviews, 12, e582-e592.

http://dx.doi.org/10.1111/j.1467-789X.2011.00881.x

[15] Aekplakorn, W. and Mo-Suwan, L. (2009) Prevalence of Obesity in Thailand. Obesity Reviews, 10, 589-592. http://dx.doi.org/10.1111/j.1467-789X.2009.00626.x

[16] Rojroongwasinkul, N., Kijboonchoo, K., Wimonpeerapattana, W., Purttiponthanee, S., Yamborisut, U., Boonpraderm, A., et al. (2013) SEANUTS: The Nutritional Status and Dietary Intakes of 0.5-12 Year-Old Thai Children. British Journal of Nutrition, 110, S36-S44. http://dx.doi.org/10.1017/S0007114513002110

[17] Guenther, P.M., Kott, P.S. and Carriquiry, A.L. (1997) Development of an Approach for Estimating Usual Nutrient Intake Distributions at the Population Level. Journal of Nutrition, 127, 1106-1112.

[18] Jahns, L., Arab, L., Carriquiry, A. and Popkin, B.M. (2005) The Use of External Within-Person Variance Estimates to Adjust Nutrient Intake Distributions over Time and across Populations. Public Health Nutrition, 8, 69-76. http://dx.doi.org/10.1079/PHN2005671

[19] Nusser, S.M., Carriquiry, A.L., Dodd, K.W., Fuller, W.A. and Jensen, H.H. (1996) A User's Guide to C-SIDE (Soft Ware for Intake Distribution Estimation). Version 1.0, Technical Report 96-TR31, Center for Agricultural and Rural Development Ames, Iowa State University, Ames.

[20] Varela-Silva, M.I. and Bogin, B. (2012) Leg Length and Anthropometric Applications: Effects on Health and Disease. In: Preedy, V.R., Ed., Handbook of Anthropometry: Physical Measures of Human Form in Health and Disease, Springer Science \& Business Media, New York, 769-783. http://dx.doi.org/10.1007/978-1-4419-1788-1_43

[21] Langenberg, C., Hardy, R., Kuh, D. and Wadworht, M.E. (2003) Influence of Height, Leg and Trunk Length on Pulse Pressure, Systolic and Diastolic Blood Pressure. Journal of Hypertension, 21, 537-543. http://dx.doi.org/10.1097/00004872-200303000-00019

[22] Lawlor, D.A., Davey Smith, G. and Ebrahim, S. (2003) Association between Leg Length and Offspring Birthweight: Partial Explanation for the Trans-Generational Association between Birthweight and Cardiovascular Disease: Findings from the British Women's Heart and Health Study. Paediatric and Perinatal Epidemiology, 17, 148-155. http://dx.doi.org/10.1046/j.1365-3016.2003.00479.x

[23] Dekkers, C., Podolsky, R.H., Treiber, F.A., Barbeau, P., Gutin, B. and Snieder, H. (2004) Development of General and 
Central Obesity from Childhood into Early Adulthood in African American and European American Males and Females with a Family History of Cardiovascular Disease. The American Journal of Clinical Nutrition, 79, 661-668.

[24] Fumagalli, F., Monteiro, J.P., Sartorelli, D.S., Vieira, M.N.C.M. and Bianchi, M.L.P. (2008) Validation of a Food Frequency Questionnaire for Assessing Dietary Nutrients in Brazilian Children 5 to 10 Years of Age. Nutrition, 24, 427432. http://dx.doi.org/10.1016/j.nut.2008.01.008

[25] Health System Research Institute (2009) Survey of Food Consumption of Thai People. The 4th National Health Examination Survey, 2008-2009, National Health Examination Survey Office, Nonthaburi.

[26] Thai Food Based Dietary Guideline Working Group (2009) Nutrition Flag Manual. Ministry of Public Health, Department of Health.

[27] Wu, S.J., Pan, W.-H., Yeh, N.-H. and Chang, H.-Y. (2007) Dietary Nutrient Intake and Major Food Sources: The Nutrition and Health Survey of Taiwan Elementary School Children 2001-2002. Asia Pacific Journal of Clinical Nutrition, 16, S518-S533.

[28] Im, J.G., Kim, S.H., Lee, G.-Y., Joung, H. and Park, M.-J. (2013) Inadequate Calcium Intake Is Highly Prevalent in Korean Children and Adolescents: The Korea National Health and Nutrition Examination Survey (KNHANES) 2007-2010. Public Health Nutrition, 17, 2489-2495.

[29] Gerosa, S. and Skoet, J. (2013) Milk Availability: Current Production and Demand and Medium-Term Outlook. In: Muehlhoff, E., Bennett, A. and McMahon, D., Eds., Milk and Dairy Products in Human Nutrition, Food Agricultural Organization, Rome, 11-40.

[30] Rampersaud, G.C., Bailey, L.B. and Kauwell, G.P. (2003) National Survey Beverage Consumption Data for Children and Adolescents Indicate the Need to Encourage a Shift toward More Nutritive Beverages. Journal of the American Dietetic Association, 103, 97-100. http://dx.doi.org/10.1053/jada.2003.50006

[31] Fisher, J.O., Mitchell, D.C., Smicklas-Wright, H. and Birch, L.L. (2001) Maternal Milk Consumption Predicts the Trade-Off between Milk and Soft Drinks in Young Girls’ Diets. Journal of Nutrition, 131, 246-250.

[32] dos Santos, L.C., de Padua Cintra, I., Fisberg, M. and Martini, L.A. (2008) Calcium Intake and Its Relationship with Adiposity and Insulin Resistance in Post-Pubertal Adolescents. Journal of Human Nutrition and Dietetics, 21, 109-116. http://dx.doi.org/10.1111/j.1365-277X.2008.00848.x

[33] Carruth, B.R. and Skinner, J.D. (2001) The Role of Dietary Calcium and Other Nutrients in Moderating Body Fat in Preschool Children. International Journal of Obesity, 25, 559-566. http://dx.doi.org/10.1038/sj.ijo.0801562

[34] Lappe, J.M., Rafferty, K.A., Davies, K.M. and Lypaczewski, G. (2004) Girls on a High-Calcium Diet Gain Weight at the Same Rate as Girls on a Normal Diet: A Pilot Study. Journal of the American Dietetic Association, 104, 1361-1367. http://dx.doi.org/10.1016/j.jada.2004.06.025

[35] Barba, G. and Russo, P. (2006) Dairy Foods, Dietary Calcium and Obesity: A Short Review of Evidence. Nutrition, Metabolism and Cardiovascular Diseases, 16, 445-451. http://dx.doi.org/10.1016/j.numecd.2006.04.004

[36] Parikh, S.J. and Yanovski, J.A. (2003) Calcium Intake and Adiposity. The American Journal of Clinical Nutrition, 77, 281-287.

[37] Zemel, M.B. (2004) Role of Calcium and Dairy Products in Energy Partitioning and Weight Management. The American Journal of Clinical Nutrition, 79, S907-S912.

[38] Spence, L.A., Cifelli, C.J. and Miller, G.D. (2011) The Role of Dairy Products in Healthy Weight and Body Composition in Children and Adolescents. Current Nutrition \& Food Science, 7, 40-49.

http://dx.doi.org/10.2174/157340111794941111 